\title{
HUMAN-GEOGRAPHICAL FACTORS OF FINANCIAL INFRASTRUCTURE DEVELOPMENT IN THE WESTERN REGION OF UKRAINE
}

\author{
Zlata KACHMARYK \\ Ivan Franko National University of Lviv, Ukraine \\ zlata.kachmaryk@gmail.com
}

\begin{abstract}
The article provides a brief analysis of socio-geographical factors that have a decisive influence on the formation of financial infrastructure in the Western region of Ukraine. Traditional and innovative factors that are stimulating and limiting are highlighted. Among the main factors, emphasis is placed on geographical location, historical and geographical features, economic and geographical, socio-geographical, international cooperation and investment flows. The development of the financial network is not only under the influence of regional factors, but also in line with national and global trends. Despite the fact that the financial infrastructure of the state began to form with independence in 1991, and in the Western region the first prototype network of financial infrastructure began to form in the XVII century, today it is still in its infancy. However, this makes it possible to build the financial infrastructure in accordance with today's challenges. For the sake of balanced development it is necessary to take into account the factors that not only promote development, but also inhibit it. The financial infrastructure is characterized by significant diversification, so special attention is paid to the factors that are inherent in each component. Banking, credit infrastructure and the infrastructure of mutual investment institutions are more developed in contrast to other components. Socio-geographical factors affect each individually and together, thus showing a synergistic effect. The peculiarity of these factors is also their multiplier effect, which is traced in the chain changes during the transformation of the factor itself. The geographical location of the region has a positive impact on the development of financial infrastructure, which is reflected in the developed network of international and national transport corridors, which provides trade growth, as well as strong international, including cross-border, cooperation in many sectors.

Key words: financial infrastructure, regional financial infrastructure, development factors, financial services market, banking institutions, insurance companies, investment funds.
\end{abstract}

DOI: https://doi.org/10.17721/2413-7154/2020.84.55-66

UDC: 911.3

Received: October 30, 2020.

Revised: December 8, 2020.

Accepted: December 15, 2020.

\section{СУСПІЛЬНО-ГЕОГРАФІЧНІ ЧИННИКИ РОЗВИТКУ ФІНАНСОВОЇ ІНФРАСТРУКТУРИ ЗАХІДНОГО РЕГІОНУ УКРАЇНИ}

\section{ЗЛата КАЧМАРИК}

Львівський національний університет імені Івана Франка, Україна zlata.kachmaryk@gmail.com

\begin{abstract}
Анотація: У статті здійснено короткий аналіз суспільно-географічних чинників, які мають вирішальний вплив на формування фінансової інфраструктури у Західному регіоні України. Виділено традиційні та інноваційні чинники, які характеризуються стимулюючим та обмежуючим характером. Серед основних чинників наголос зроблено на географічному положенні, історико-географічних особливостях, економікогеографічному, соціально-географічному, міжнародному співробітництві та інвестиційних потоках. Розвиток фінансової мережі відбувається не тільки під впливом регіональних чинників, а також у руслі загальнодержавних та загальносвітових тенденцій. Сучасна фінансова інфраструктура держави почала своє формування із здобуттям незалежності у 1991 році, а у Західному регіоні перша прототипна мережа фінансової інфраструктури почала формуватися ще у XVII столітті, сьогодні вона все ще перебуває на етапі становлення. Проте це дає змогу розбудувати фінансову інфраструктуру відповідно до викликів сьогодення. Задля збалансованого розвитку необхідно врахувати чинники, що не тільки сприяють розвитку, а й гальмують його. Фінансова інфраструктура характеризується значною розгалуженістю, тому особливу увагу приділено чинникам, що є притаманними для кожної складової. Банківська, кредитна інфраструктура та інфраструктура інститутів спільного інвестування $\epsilon$ більш розвинутою порівняно з іншими компонентами. Суспільно-географічні чинники впливають як кожен окремо, так і разом, тим самим проявляючи синергетичну дію. Особливістю цих чинників також $\epsilon$ їхній мультиплікаційний ефект, який прослідковується у ланцюгових змінах при трансформації самого чинника. Географічне положення регіону позитивно впливає на розвиток фінансової інфраструктури, що знайшло своє відображення у розвиненій мережі міжнароднихтанаціональних транспортних коридорів, що забезпечує зростання торгівлі, а також потужному міжнародному, у тому числі транскордонному, співробітництві у багатьох галузях економіки.
\end{abstract}

Ключові слова: фінансова інфраструктура, регіональна фінансова інфраструктура, чинники розвитку, ринок фінансових послуг, банківські установи, страхові компанії, інвестиційні фонди. 
Постановка проблеми. Задля економічного зростання Західного регіону та України важливою $є$ розвинена фінансова інфраструктура, яка забезпечує належне функціонування в контексті ринку фінансових послуг. Відповідно, необхідною умовою $€$ стабільне зростання усіх компонентів фінансової інфраструктури. Суспільно-географічний аналіз дає змогу найбільш комплексно розглянути особливості дії чинників, зокрема геопросторові. На сьогодні рівень розвитку окремих компонентів фінансової інфраструктури перебуває на етапі становлення, тому існують ризики, які можуть бути спричинені слабким рівнем розвитку окремих структурних елементів, що може призвести до негативних наслідків. Беручи до уваги, що фінансова інфраструктура включає в себе значну кількість підрозділів, необхідно розглянути вплив кожного чинника. Окрім цього, оскільки фінансова інфраструктура перебуває в процесі становлення, то врахувавши дії суспільно-географічних факторів можна розбудовувати таку інфраструктуру, яка відповідатиме вимогам сучасності, оминаючи деякі етапи розвитку, які не знайшли належного застосування.

Аналіз останніх досліджень та публікацій. Значна кількість досліджень проведена економістами, зокрема О. Іваницькою (Ivanytska, 2005, 2006), 3. Криховецькою (Krykhovetska, 2014), М. Кужелєвим (Kuzhelev, 2015), В. Онищенком, а також юристами та фахівцями 3 міжнародних відносин. Ця тематика досліджується у працях українських та зарубіжних вчених з суспільної географії та окремих іï галузей, зокрема С. Запотоцького (Zapotockiy, 2013), Ю. Качаєва (Kachaev, 2000), О. Мамчур (Mamchur, 2018), О. Шаблія (Shabliy, 2012) та інших. Для дослідження використано матеріали Національного банку України, матеріали збірників Державної служби статистики України, інформацію з Єдиного державного веб-порталу відкритих даних, публікації у тематичних періодичних виданнях, монографіях та збірниках у галузі суспільної географії i економічної науки.

Мета статті полягає у висвітленні впливу суспільно-географічних чинників на формуванні та розвитку фінансової інфраструктури Західного регіону України загалом та окремих її компонентів задля збалансованого розвитку ринкової системи економіки.

\section{Виклад основного матеріалу}

Протягом останніх 30 років відбувається перманентна трансформація фінансової інфраструктури, як і усієї економічної і соціальної сфери розвитку цілої економічної системи. Від початку 90-х pp. ХХ ст. почалось формування фінансової інфраструктури, що супроводжувалося змінами різного роду. Після суспільно-політичних зрушень Революції Гідності в Україні розпочалася трансформація усіх систем, у тім числі й економічної. Відповідно, нині відбувається низка реформ як на загальнодержавному, так і на регіональному рівнях, що мають на меті пере- та добудувати необхідні інститути інфраструктури для функціонування ринкової економіки.

Фінансова інфраструктура - поняття, що відображає взаємозв'язок кількох сфер, зокрема економічної, фінансової та соціальної. Фінансова інфраструктура відіграє вирішальну роль в ефективному наданні фінансових послуг. Перш за все, основу для розвитку фінансової системи забезпечує фінансова інфраструктура.

Фінансова інфраструктура $є$ сукупністю інститутів та організацій, науково-методичних $\mathrm{i}$ кадрових елементів, що забезпечує неперервну, прозору й надійну основу функціонування фінансового ринку в його динамічному розвиткові, переміщення та розподіл потоків капіталів між секторами, суб'єктами й об'єктами ринку (Ivanytska, 2005). До установ фінансової інфраструктури належать банки (з мережею своїх установ - філій, відділень тощо), страхові компанії (брокери), інвестиційні, кредитні, пенсійні фонди, розрахункові установи, установи, що проводять операції 3 цінними паперами, компанії фінансового лізингу, компанії із надання та реалізації концесій (Ivanytska, 2006). Регіональна фінансова інфраструктура це складова національної інфраструктури, яка підпорядковується загальнодержавному чинному законодавству, складається з дрібніших компонентів, проте забезпечення виконання функцій залежить від специфіки регіону (господарство, людність, наявність/відсутність регіоноформуючих підприємств, інвестиційна привабливість регіону тощо).

Розвинена інфраструктура визначає основу фінансової системи країни загалом. При слабкому розвитку фінансової інфраструктури країни з'являються значні обмеження для фінансових установ, які прагнуть розширити свою пропозицію фінансових послуг - кредитних, ощадних та платіжних, що відображається на рівні економіки. У подальшому можуть спричинити фінансові кризи, що відображає ризики для фінансової системи загалом. Найчастіше до елементів фінансової інфраструктури, що є слаборозвиненими, належать бюро кредитних історій, розрахунки 3 цінними паперами, системи переказів та здійснення застави та функціонування платежів. При високому рівні розвитку цих сфер забезпечується підвищення прозорості та забезпечення фінансової стабільності на фінансових ринках (Kachmaryk, 2018).

Для розвитку фінансової інфраструктури регіону суспільно-географічні чинники мають вагомий вплив. Чинник географічного, особливо економіко- і транспортного положення регіону значною мірою визначає місце району у національному комплексі країни, а також на міждержавному і світовому рівнях (International Bank of Reconstruction and Development, 2020). До основних чинників належать географічне положення та його різновиди (історико- 
географічний, економіко-географічний, соціальногеографічний), інноваційні тощо. Суспільногеографічні чинники виступають у ролі тригерів, які дають змогу відбуватися процесам безпосередньо або побічно пов'язаних з ними. Також відзначаємо, що суспільно-географічні чинники мають мультиплікаційний ефект. Тому, коли один 3 чинників зазнає значних змін, зміна будь-якої 3 перелічених складових зумовлює множинний ефект. Окрім, при впливі суспільно-географічних чинників також йдеться про синергетичну дію: у системі фінансової інфраструктури можливі різні поєднання та самоорганізація іiї складових. Едгар Петерс визначає фінансовий ринок, а отже i фінансову інфраструктуру, як синергетичну систему $з$ певним характерним станом, від якого система постійно відхиляється під дією зовнішніх та внутрішніх факторів (Peters, 1996).

Суспільно-географічні чинники поділяються на традиційні (географічне положення, історико-, економіко-, соціально-географічні) та інноваційні. Незважаючи на те, що дія суспільно-географічних чинників має комплексний характер, розглянемо їх детально. Також відзначаємо, що чинники виступають не тільки як стимулюючі, а й окремі 3 них несуть обмежуючий характер.

Суспільно-географічне положення. Об'єктом дослідження є фінансова інфраструктура Західного регіону України, який охоплює вісім областей. До нього належать Волинська, Закарпатська, ІваноФранківська, Львівська, Рівненська, Тернопільська, Хмельницька, Чернівецька області, загальна площа досліджуваного ареалу - 131 млн км², що становить приблизно п’яту частину усієї території України. Завдяки транскордонному співробітництву, на територіях, прилеглих до кордонів (особливо поблизу контрольно-пропускних пунктів) створюється відповідна інфраструктура. Зокрема, виникла необхідність у створенні таких об'єктів фінансової інфраструктури, як відділення страхових компаній та банківських установ.

Одним із чинників розвитку фінансової інфраструктури $\epsilon$ суспільно-географічне положення. Не зважаючи на те, що більшість областей Західного регіону України займають периферійне положення щодо розташування столиці, регіон має характерне вигідне геоекономічне та геостратегічне положення. Це проявляється у тому, що через шість з восьми областей проходить державний кордон України 3 шістьма країнами, при цьому п'ять областей 3 них межує 3 чотирма країнами Європейського Союзу, будучи “воротами" до країн-членів ЄC (Mamchur, 2018). Завдяки такому суспільно-географічному розташуванню сформувалась значна мережа міжнародних та національних транспортних коридорів, що забезпечує зростання торгівлі, а також забезпечує міжнародне, у тому числі транскордонне, співробітництво у багатьох галузях економіки. Економіко-географічне положення відіграє вагому роль серед чинників, що пояснюється тим, що це просторове відношення об'єкта (поселення, району, держави тощо) до геоекономічних даностей: важливих районів, вузлів і центрів господарського життя, економічно розвинених держав та їхніх груп, торгово-транспортних шляхів i ринків товарів, капіталів, ноу-гау, праці тощо (Shabliy, 2012). Саме ці геоекономічні даності несуть для нього господарське значення.

Історико-географічні чинники. Рисою, що характеризує Західний регіон України, є особливі історико-географічні передумови. Зокрема, на території історичних регіонів Галичини i Буковини збереглися ринкові традиції функціонування фінансових установ попередніх століть, які віднайшли своє відображення у сучасності, формуючи вже фінансову інфраструктуру в умовах незалежної України. Зважаючи на традиції підприємництва i банківської справи, на початку 1990-х років у Західному регіоні було засновано ряд місцевих банків з мережею їх філій.

Процес формування фінансової інфраструктури на території Західного регіону України розпочався ще у XVII столітті. Саме у цей період з'явились перші прототипи банківських установ. Однак активна фаза розвитку фінансової інфраструктури припала на другу половину XIX ст.

Найбільшого розвитку зазнала банківська інфраструктура. Перші банки, що з'явились у Львові, були засновані релігійними громадами та спеціалізувалися на іпотечних позиках i короткострокових кредитах (Moshenskyi, 2014). Проте на теренах Галичини i Буковини не було центральних кредитних установ, а тільки філії та відділення іноземних банків, що вилилось у проблему: сильно відчувалась нестача фінансових ресурсів для належного функціонування кредитнофінансових установ.

Банки нового типу в Галичині з'явилися у середині XIX ст. як філії австрійських банків. Також у цей період розпочалось формування інфраструктури ринку цінних паперів. Важливим економічним центром був Львів. На початку XX ст. у Львові налічувалося 84 кредитно-фінансові установи (забезпеченість мережею приблизно 1,5-2,0 тис. осіб/ відділення), у Києві - 42 відділення (забезпеченість мережею понад 10 тис. осіб/відділення). Відповідно, розвиненість Львівської мережі (австро-угорська фінансова система) була значно вищою, ніж Київської (фінансова система Російської імперії) (Kachmaryk, 2020).

На Буковині банківська інфраструктура розпочала формуватися у середині XIX ст.: окрім філій австрійських банків, почали з'являтися i львівські. Перший місцевий банк був створений у 1870 р. Станом на початок XX ст. на Буковині було утворено 217 банківських та небанківських (державних та акціонерних) фінансових установ, 3 яких було 5 філій місцевих банків і 9 філій австроугорських та румунських), що свідчить про значну розгалуженість мережі.

Історико-географічні особливості спричинили формування специфічної бізнес-мережі, яка сьогодні продовжує свій розвиток у Західному 
регіоні України. Причиною такого особливого суспільно-географічного розвитку Західного регіону України є те, що Україна упродовж значного терміну була аграрно-сировинним доповненням інших країн, тим самим сильно різнився розвиток від других західноєвропейських регіонів. У цих західноєвропейських регіонах часом простежувалася куди нижча спроможність до накопичення грошового капіталу у вигляді коштів, а також ступінь виробництва товарів та послуг.

Метрополійність Львова, яку ми спостерігаємо за сьогоденним Львовом у розрізі регіону, була закладена ще у XVII столітті і позиціонувала Львів як головний фінансовий центр Галичини. Натомість 3 кінця XIX - початку XX століття стає яскраво вираженим нерівномірний розвиток кредитно-фінансової системи Галичини, Буковини i Закарпаття, причиною чому стали тогочасні загальноєвропейські фінансові кризи.

Сочуіально-географічні чинники. Особливим суспільно-географічним чинником для становлення фінансової інфраструктури Західного регіону $\epsilon$ соціально-географічний розвиток, що характеризується такими важливими показниками як геопросторові особливості людності, структура людності, демографічне навантаження населення, рівень доходів населення, зайнятість тощо, які визначають інтенсивність та рівень розвитку фінансової інфраструктури загалом та іiі компонентів. Відповідно, в залежності від геопросторових особливостей розміщення населення та його демографічно-соціальних особливостей виникають різні групи споживачів, яким необхідні особливі послуги. Це проявляється у специфічних зарплатних проектах, пенсійних проектах, таких як недержавні пенсійні фонди (НПФ), для функціонування яких потрібні конкретні компоненти фінансової інфраструктури.

Геопросторовою особливістю розміщення населення у Західному регіоні України є майже однакова чисельність у областях регіону. Людність Західного регіону України станом на 1 січня 2020 р. становила 10,47 млн осіб. Відповідно, у регіоні зосереджено 25\% усього населення України. За кількістю населення адміністративні області характеризуються таким чином: для 638 областей чисельність населення налічується приблизно однакова - понад 1 млн осіб, ще одна область налічує понад 2,5 млн осіб - Львівська. Натомість, чисельність Чернівецької області не сягає 1 млн осіб.

Як і в Україні, у регіоні дослідження відбувається скорочення кількості населення. Наприклад, 32015 по 2020 pp. (State Statistics Service of Ukraine, 2020) людність регіону значно скоротилась, при цьому найбільше зменшення відбулось у Хмельницькій області - близько $20 \%$ від областей регіону, у Львівській області - понад 19\% та у Тернопільській - понад 15\%. Натомість, у розрізі міського населення у Тернопільській області спостерігається приріст населення, решта областей характеризуються від'ємними показниками: найбільше скорочення спостерігається у містах Львівської області, а також Волинської та Рівненської областей. Але у розрізі обласних центрів у більшості випадків відбувається приріст міського населення. Лідерами за додатніми показниками є міста Хмельницький, Тернопіль та Івано-Франківськ. У сільській місцевості областей Західного регіону України також спостерігається скорочення населення, найбільше це спостерігається у Хмельницькій, Тернопільській та Львівській областях.

Враховуючи що більшість об'єктів фінансової інфраструктури зосереджено у містах, в областях регіону наявна значна кількість доріг 3 поганим покриттям, що особливо помітно у сільській місцевості, а також по регіону присутній високий рівень зношеності громадських транспортних засобів.

Варто зазначити, що частка фінансового ринку Західного регіону у створенні ринку держави не $\epsilon$ лідируючою за кількістю банків та юридичних осіб інших компонентів інфраструктури ринку та їх рівня розвитку. Проте у просторовому відношенні достатньо високим $\epsilon$ відсоток, що припадає на фінансовий ринок Львівської області, який становить близько половини фінансових послуг серед Західних областей).

Ще одним чинником, що впливає на формування фінансової інфраструктури $є$ демографічне навантаження на населення у віці 15-64 роки. При цьому, кількість економічно активного населення регіону працездатного віку у 2019 р. склала 4,5 млн осіб, а це 42,4\% від населення усього регіону. Загальне демографічне навантаження на населення у віці 15-64 роки в середньому у Західному регіоні України становить майже 473 особи на 1000 осіб проти 480 осіб на 1000 осіб по Україні (станом на 1 січня 2020 року (State Statistics Service of Ukraine, 2020)). Незважаючи на те, що порівняно 3 ідентичними показниками 2015 року, у 2020 році зросло навантаження, проте у загально державному плані у регіоні навантаження менше, ніж у інших. Відповідно, загальне демографічне навантаження на населення працездатного віку у Західному регіоні України нижче, ніж середньо український показник.

Геопросторові особливості розподілу розміру середньомісячної зарплатні по регіону дослідження характеризуються нижчим рівнем, ніж середньоукраїнський. Наприклад, станом на 1 січня 2020 року, середньомісячна заробітна плата в Україні становила 10771 грн, в той час як цей показник в середньому по регіону дослідження становив 8657 грн. У жодній 3 областей Західного регіону України нема показника, що б перевищував середню українську заробітну плату. Середньомісячна зарплатня у Тернопільській області становила 7068 грн - найменша не тільки у регіоні, а й по Україні загалом (State Statistics Service of Ukraine, 2020).

За рівнем зайнятості населення у віці 15 років і старше станом на 2019 р. Західний регіону України характеризується середньоукраїнськими показниками - приблизно 51-52\%, при цьому найвищі 
Таблиця 1

Людність Західного регіону України, 2020 р., осіб

\begin{tabular}{|l|r|c|c|}
\hline \multicolumn{1}{|c|}{ Область } & Людність & В т. ч. у міській місцевості & В т. ч. у сільській місцевості \\
\hline Волинська & 1031421 & 539179 & 492242 \\
\hline Закарпатська & 1253791 & 465904 & 787887 \\
\hline Івано-Франківська & 1368097 & 606764 & 761333 \\
\hline Львівська & 2512084 & 1534040 & 978044 \\
\hline Рівненська & 1152961 & 548088 & 604873 \\
\hline Тернопільська & 1038695 & 473727 & 564968 \\
\hline Хмельницька & 1254702 & 720752 & 533950 \\
\hline Чернівецька & 901632 & 390551 & 511081 \\
\hline
\end{tabular}

*Складено автором за (State Statistics Service of Ukraine, 2020)

Таблиияя 2

Демографічне навантаження на населення у віці 15-64 роки (на 1000 осіб у віці 15-64 роки), дані за 2020 р.

\begin{tabular}{|c|c|c|c|c|c|c|c|c|c|}
\hline \multirow[b]{2}{*}{ Область } & \multicolumn{3}{|c|}{ Загальне навантаження } & \multicolumn{3}{|c|}{$\begin{array}{c}\text { Навантаження особами у } \\
\text { віці 0-14 років } \\
\end{array}$} & \multicolumn{3}{|c|}{$\begin{array}{l}\text { Навантаження особами у } \\
\text { віці } 65 \text { років і старше }\end{array}$} \\
\hline & 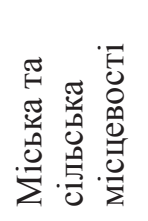 & 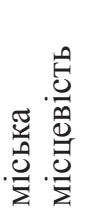 & 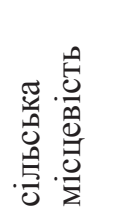 & 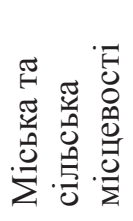 & . & 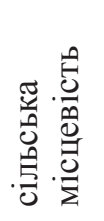 & 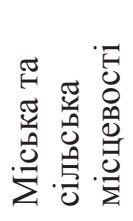 & . & 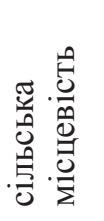 \\
\hline Волинська & 490 & 450 & 534 & 294 & 265 & 325 & 196 & 185 & 209 \\
\hline Закарпатська & 468 & 469 & 468 & 291 & 288 & 293 & 177 & 181 & 175 \\
\hline Івано-Франківська & 457 & 426 & 482 & 248 & 231 & 262 & 209 & 195 & 220 \\
\hline Львівська & 456 & 439 & 484 & 238 & 225 & 260 & 218 & 214 & 224 \\
\hline Рівненська & 494 & 436 & 549 & 305 & 258 & 351 & 189 & 178 & 198 \\
\hline Тернопільська & 457 & 424 & 486 & 230 & 230 & 230 & 227 & 194 & 256 \\
\hline Хмельницька & 495 & 439 & 575 & 237 & 234 & 239 & 258 & 205 & 336 \\
\hline Чернівецька & 465 & 420 & 501 & 253 & 222 & 279 & 212 & 198 & 222 \\
\hline
\end{tabular}

${ }^{*}$ Складено автором за (State Statistics Service of Ukraine, 2020)

показники присутні у Чернівецькій та Рівненській областях, a y Тернопільській і Волинській найнижчі (State Statistics Service of Ukraine, 2020).

Економіко-географічні чинники характеризуються тим, що досить різняться між собою за структурою і рівнем всіх галузей господарства, за їх територіальним розміщенням і сполученням, специфіці технологічних процесів тощо.

До економіко-географічних чинників належать:

- економіко-географічне положення регіону (розташування певного об'єкта стосовно до інших, які мають для нього економічне значення);

- геопросторові особливості розвитку економічної системи регіону;

- наявність достатньої кількості кваліфікованих кадрів;
- рівень розвитку зовнішніх і внутрішніх економічних зв'язків цього регіону.

Важливою передумовою для розвитку фінансової інфраструктури в регіоні та Україні загалом $\epsilon$ перехід до ринкових методів господарювання. Такий процес призвів до появи нових суб'єктів господарювання на фінансовому ринку шляхом переходу державних об'єктів у приватну власність через їх приватизацію, тому з'явилися комерційні продавці i покупці. Також це дозволило з'явитись новим елементам фінансової інфраструктури, наприклад лізинговим та страховим компаніям, а також утворити ланку фінансової інфраструктури, що виконують роль неекономічних агентів, таких як реєстратори, депозитарії, валютні та фондові біржі, торговельно- 
інформаційні системи (Fedosov, 2017). Тим самим поява нових організаційних посередників призвела до розвитку мережі особливих фінансових інститутів задля забезпечення посередництва поміж продавцями й покупцями фінансових послуг (наприклад, інститути спільного інвестування, факторингові та лізингові компанії, депозитаріі). Також, враховуючи те, що перестала існувати державна монополія щодо грошових вкладів громадян, поява відносно вільних грошей сприяла розвитку конкурентної ситуації між різними дійовими особами фінансової інфраструктури. Отже, у населення з'явилась можливість обирати шляхи інвестування власних коштів (наприклад, депозитні вклади, поліси страхування, придбання дорогоцінних металів, вклади в інститути спільного інвестування, купівля цінних паперів тощо).

Для регіону дослідження характерними $\epsilon$ геопросторові особливості розміщення малого підприємництва, які відрізняють його від інших регіонів. Якщо малий бізнес надалі розвиватиметься, то це дасть змогу йому бути одним із ключових джерел економічного зростання. Саме малий бізнес постраждав найбільше у зв'язку з карантином, спричиненим COVID-19, та локдауном, що для багатьох підприємств завершились закриттям. Розвиток малого бізнесу також потребує значного вдосконалення у розширенні його мереж. Суб'єкти малого підприємництва, особливо такі, що розміщені на периферійних територіях регіону дослідження, $\epsilon$ дещо обмеженими у pecypcax, а також для них існує певна складність у доступі до матеріально-технічного забезпечення. Таким чином, виникають певні бар'єри, що обмежують зростання та розвиток їхньої діяльності. Як результат, фінансова інфраструктура не отримує підгрунтя для свого розвитку. Задля вирішення такої негативної тенденції 3 метою подальшого уникнення подібних негараздів, необхідно налагоджувати нові та посилювати вже утворені кооперативні зв'язки, адже це дасть змогу утворити сукупну базу, яка забезпечить інфраструктурою не тільки фінансовою, а й матеріально-технічного та інформаційно-аналітичного забезпечення, консолідація ресурсів та зусиль для виробництва i збуту продукції, зниження рівня виробничих $\mathrm{i}$ трансакційних витрат, покращення доступності фінансування, підвищення інвестиційної привабливості (National Institute for Strategic Studies, 2013a).

Водночас 3 великою кількістю підприємств малого та середнього бізнесу, загалом для регіону не характерні містоформуючі промислові підприємства, які розташовуються хаотично. Для продуктивного розвитку фінансової інфраструктури, необхідні такі умови: стрімкий позитивний розвиток економіки країни, стабільність у законодавчій сфері, низькі темпи інфляції, придатна політична ситуація, а також інвестиції (як зовнішні, так і внутрішні).
Окрім цього, світовий розвиток особливостей фінансової інфраструктури безпосередньо вплинув на впровадження нового функціонування. Банківські установи завдяки розвиненій мережі та швидкому залученню інновацій почали надавати не тільки кредитно-фінансові послуги, а також стали можливі послуги, які надавались окремими, конкретними суб'єктами фінансової інфраструктури, такі як лізингові, факторингові, брокерські та інші. Ще одним чинником задля розвитку внутрішньодержавного валютного ринку, а також появі економічних суб'єктів на світовому ринку стало виключення державної валютної монополії.

Серед економіко-географічних чинників основою становлення i розвитку фінансової інфраструктури є просторові особливості економічного рівня розвитку території. Чинниками, що характеризується комплексністю показників, виступає валовий регіональний продукт та валовий регіональний продукт у розрахунку на 1 особу.

Відповідно, таким показником, що відображає рівень розвитку економіки Західного регіону України, а тим самим і чинить вплив на формування та функціонування фінансової інфраструктури, $є$ геопросторові особливості валового регіонального продукту (ВРП). Також цей показник $\epsilon$ основною характеристикою ефективності регіональної фінансової політики.

Зі здобуттям Україною незалежності, з 90-х рр. XX ст., області, що охоплює Західний регіон України, не посідають провідних позицій за загальними економічними показниками. Це пояснюється наявністю незначної кількості у Західному регіоні великих виробничо-промислових підприємств. Наприклад, жодна із західних областей не входить до п'ятірки регіонів, економіка яких має найвищий рівень індустріалізації (Kravtsiv, 2018). Для ІваноФранківської та Рівненської областей частка промислової продукції в обсязі реалізації продукції (товарів, послуг) становить понад 60\%. Не зважаючи на це, значення цього показника найбільше зросло у Тернопільській (на 17,6\%) і Закарпатській (на 11,1\%) областях. Окрім цього, починаючи з 2016 року у Західному регіоні України збільшилась експортна активність промисловості, крім Івано-Франківської i Рівненської областей (State Statistics Service of Ukraine, 2020). Відповідно, це створює диспропорції на загальнодержавному рівні.

Чільну позицію у регіоні займає Львівська область, на яку припадає майже 5\% від загального розміру ВВП держави. А загальна частка регіону становить всього близько 16\% від загальноукраїнського.

Вагомим індикатором економічного розвитку $\epsilon$ валовий регіональний продукт у розрахунку на одну особу, оскільки він відображає рівень соціально-економічного розвитку регіону. Вищий показник, ніж середній у Західному регіоні, спостерігається у Волинській, Івано-Франківській, Львівській та 


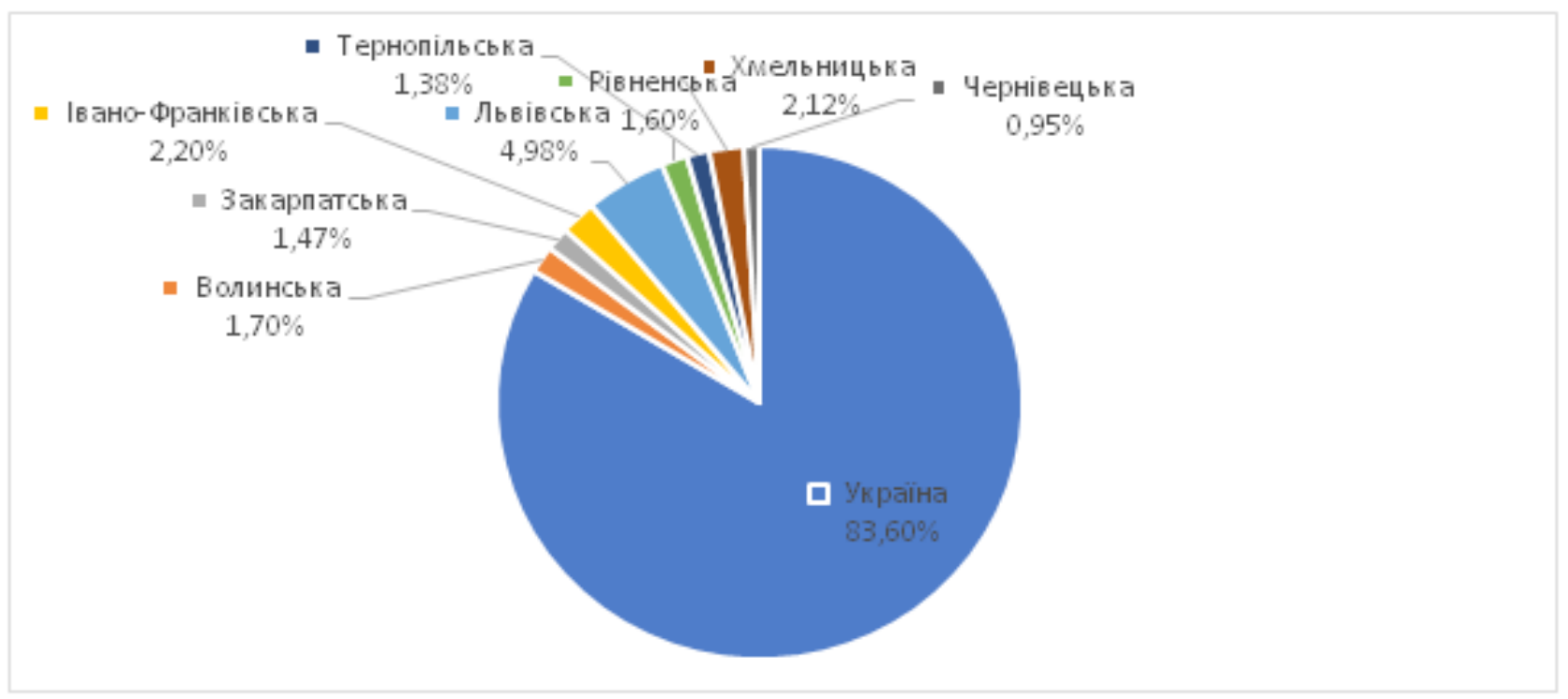

Рис. 1. Валовий регіональний продукт областей Західного регіону України, \%, 2019

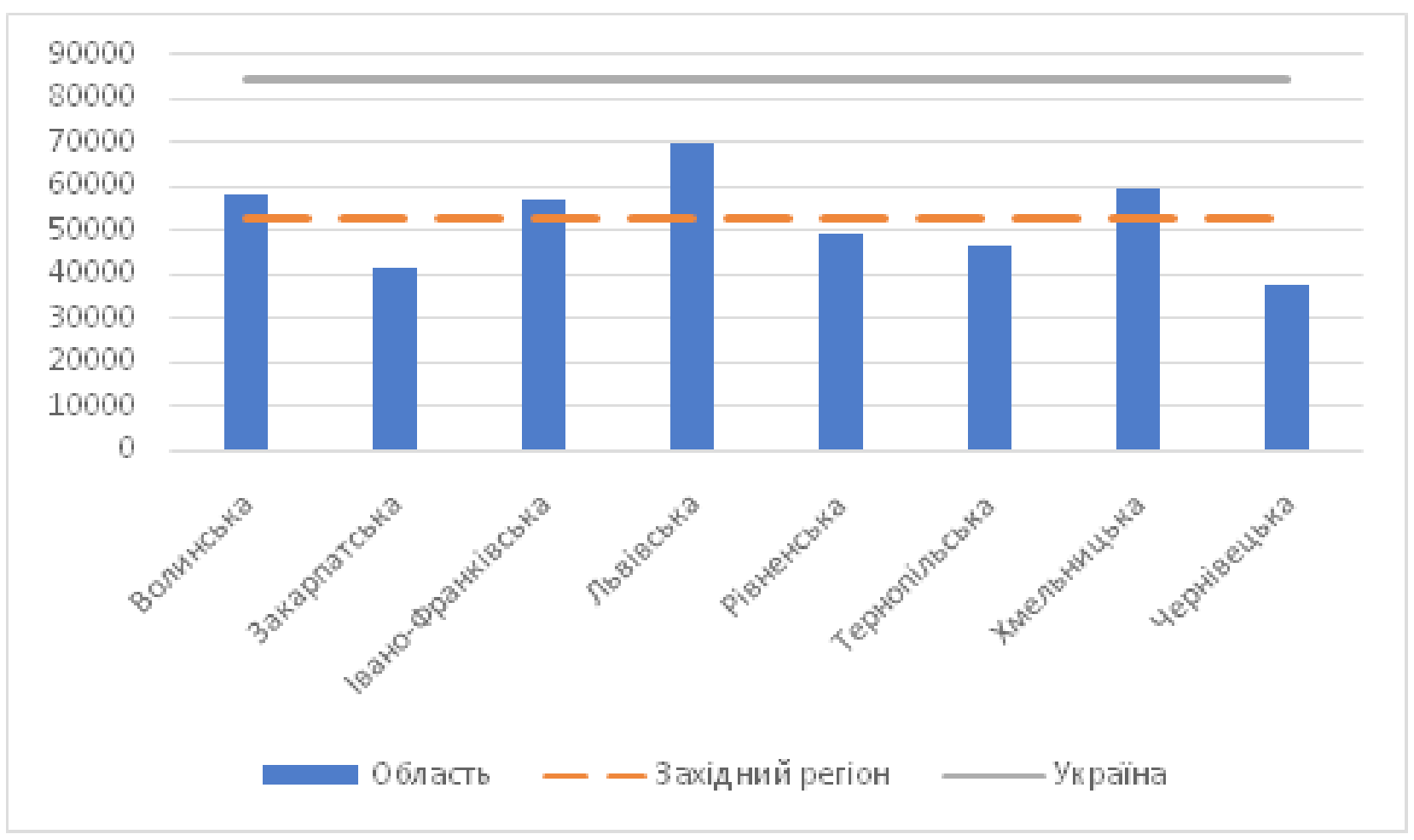

Рис. 2. Валовий регіональний продукт у розрахунку на одну особу в областях Західного регіону України, 2019

Хмельницькій областях, при цьому лише ВРП на одну особу у Львівській області близький до середньоукраїнського. Проте загальнодержавний показник на 40\% вищий, ніж середній по регіону, отже, це також сприяє розвитку диспропорцій на міжрегіональному рівні.

На функціонування та розвиток фінансової інфраструктури має вплив транспортний чинник. Часто зустрічається порівняння фінансової інфраструктури як системи доріг: кращі дороги скорочують час i витрати на проїзд, але вони також збільшують потенційну швидкість, що несе властиві ризики (International Bank for Reconstruction and Development, 2020). Відповідно, фінансова інфраструктура може або призвести до підвищення ефективності та зниження ризиків на фінансовому ринку, або сприяти надмірно небезпечним ризикам $і$ навіть призводити до світових економічних криз.

Враховуючи, що розвинена транспортна система необхідна для збалансованого розвитку соціально-економічної сфери будь-якого суспільства, тому не дивно, що вона виступає вагомим чинником дослідження соціально-економічної географії у сфері формування фінансової 
інфраструктури. Не зважаючи на те, що велика кількість фінансових операцій відбувається у віртуальному середовищі, все ж таки значна кількість операцій потребує для їхнього втілення якісних шляхів сполучення. На сьогодні, рівень транспортної інфраструктури є низький не тільки у розрізі регіону, а й усієї України. Однак, зараз відбувається реформування транспортної системи у всіх ї галузях, що забезпечується ухваленою Національною транспортною стратегією України на період до 2030 року «Drive Ukraine 2030» (Government Portal of Ukraine, 2020).

Через територію Львівської та Закарпатської областей пролягає 5-ий Пан-Свропейський транспортний коридор, що поєднує такі міста, як Венеція - Трієст/Копер - Любляна - Марибор Будапешт - Ужгород - Львів - Київ; через Львівську - простягається коридор №3: Берлін - Аахен - Кельн - Дрезден - Вроцлав - Катовіце - Краків - Львів Київ (European Commision, 2020).

Ураховуючи що більшість об'єктів фінансової інфраструктури зосереджено у великих містах, а у областях регіону наявна значна кількість доріг 3 поганим покриттям, що особливо стосується сільської місцевості, а також рівень зношеності громадських транспортних засобів, а саме на приміських напрямках, необхідно усунути наявні перешкоди.

Інноваційні чинники. У руслі розвитку близького прикордоння відбувається надходження інвестицій від країн-сусідів (Польща, Угорщина, Словаччина) (State Statistics Service of Ukraine, 2020). Це проявляється як через прямі іноземні інвестиції задля реалізації проєктів середнього та великого масштабів, так і «грошові перекази», як прояв міграційного капіталу, від фізичних осіб, які перебувають на заробітках у сусідніх країнах.

На появу таких елементів фінансової інфраструктури як фондова інфраструктура та інфраструктура фінансових послуг, вплив мала відмова від перекриття державного дефіциту шляхом вливання грошових коштів у грошовий потік на користь залучення внутрішніх та зовнішніх джерел (Meglaperidze, 2013).

Незважаючи на загалом позитивний розвиток мережі фінансової інфраструктури, прослідковується низка недоліків щодо ефективності діяльності та перспективах розвитку фінансових бірж у регіоні та становлення небанківських фінансових установ (кредитні спілки, ломбарди, лізингові компанії, довірчі товариства, страхові компанії, установи накопичувального пенсійного забезпечення, інвестиційні фонди і компаніï). За умов, що розвиток цих елементів фінансової інфраструктури матиме активний темп, як і банківська інфраструктура, вони сприятимуть становленню здорової конкуренції на фінансовому ринку не тільки у Західному регіоні, а й України загалом.

Розвинена фінансова інфраструктура забезпечує розвиток фінансового ринку, що відбувається стрімкими темпами в умовах трансформації національної економіки України. Відповідно, значною мірою це пов'язано з урахуванням регіональних особливостей, що чітко простежується на прикладі Західного регіону України.

В цей же час розростання фінансової інфраструктури, тим самим i фінансової інфраструктури, відбувається завдяки розвитку малого бізнесу. Для периферійних територій соціальноекономічний розвиток $\epsilon$ нижчим порівняно 3 районними та обласними центрами, містами обласного значення (National Institute for Strategic Studies, 2013b). У зв'язку із реформою децентралізації різниця у показниках починає зменшуватись, що у майбутньому призведе до рівномірного розвитку.

Розвиток та трансформація мережі інфраструктури значно залежить від надходження інвестицій, зокрема закордонних. Наприклад, такі банки, як «Ідея Банк», «Кредобанк» та «Банк Львів» $\epsilon$ представниками регіональних банків, кінцеві акції яких перебувають в іноземній власності. Найбільші прямі іноземні інвестиції одержуються містамиобласними центрами, а особливо Львовом, оскільки він виступає центром регіону, що відображається у його монопольності, а також Івано-Франківськом, який вже кілька років поспіль займає провідні позиції по показниках найбільшого зростання в процесі залучення прямих іноземних інвестицій. Не зважаючи на те, що Івано-Франківськ лідирує за показами інвестицій, проте у показниках ВРП це відображається прямо пропорційно. Така ж тенденція притаманна i для Рівного. Натомість, для Львова та Хмельницького це співставлення характеризуєтьсясинхронністю(State Statistics Service of Ukraine, 2020).

На розвиток фінансової інфраструктури все більший вплив мають тенденції, які активно впроваджуються у глобальному вимірі: значно посилилась концентрація грошово-промислового капіталу; фінансові ринки та їхня інфраструктура перестали бути закритими, тим самим відбулась їхня інтернаціоналізація; фінансові потоки також вийшли на глобальний рівень; значно зросла кількість учасників фінансового ринку (як покупців, так і продавців), що вимагає збільшення мережі фінансової інфраструктури, а також іiі належного рівня задля задоволення потреб користувачів; профілювання у всіх секторах економіки; політична стабільність регіону; для розвитку фінансової інфраструктури необхідна зацікавленість населення регіону, що забезпечить їі безперервний розвиток.

Варто враховувати чинники, що мають особливе місце для окремих елементів фінансової інфраструктури, оскільки ринок фінансових послуг включає в себе значну кількість підрозділів, розглянемо чинники, що є вирішальними для різних структурних одиниць.

Чинники розвитку інфраструктури валютного ринку. Інфраструктура валютного ринку забезпечує здійснення операцій 3 метою купівлі i/ або продажу як безготівкової, так і готівкової іноземної валюти, а також банківських металів. Учасниками валютного ринку України є банки 
та небанківські установи, клієнти банків, а також Національний банк (National Bank of Ukraine, 2020). Оскільки на валютному ринку відбуваються операції, що пов’язані із зовнішньо торговельними розрахунками, міграцією капіталу, туризмом тощо, то у Західному регіоні України наявні усі передумови задля його стрімкого розвитку. Серед негативних чинників простежуються такі, що гальмують цей процес. Насамперед, це зростання попиту населення на іноземні валюти. Це спричинено не тільки девальвацією гривні, а й трудовою міграційною ситуацією, яка склалася у Західному регіоні України. Часто задоволення цього попиту відбувається на так званих «чорних» валютних ринках, що зменшує надходження коштів до економіки держави, тим самим розвивається тіньова економіка. Це своєю чергою зменшує темпи розвитку офіційної інфраструктури валютного ринку, а інфраструктура «чорних» валютних ринків навпаки зазнає зростання.

Чинники розвитку інфраструктури страхового ринку. Цей сектор займає друге місце за рівнем капіталізації після банківського. Проте, територіальна мережа сформувалась 3 великими диспропорціями у регіоні. Незважаючи на те, що на ринку Західного регіону України присутня 51 страхова компанія, що мають приблизно 1000 відділень, широкою популярністю у населення вони не користуються, проте сьогодні відбувається скорочення елементів інфраструктури, що спричинене як новими вимогами, так і діджиталізацією у всіх сферах економіки (National Commission for State Regulation of Financial Services Markets, 2020). Найбільш поширеними видами страхування є послуги автострахування. Існує два види найпоширенішого страхування - обов'язкове страхування цивільно-правової відповідальності власників наземних транспортних засобів (ОСЦПВ) та добровільне страхування наземного транспорту (КАСКО), тобто страхування від усіх можливих ризиків. Проте на цьому ринку існує велика кількість махінацій як зі сторони клієнтів, так і страхових фірм, які надають ці послуги.

Незважаючи на те, що спостерігається тенденція до скорочення відділень страхової інфраструктури, у Західному регіоні це скорочення менш помітне, ніж на прикладі загальноукраїнських показників. Це спричинено особливим геополітичним розташуванням регіону дослідження. Враховуючи, що області Західного регіону України межують 3 шістьма країнами, частина населення звертається за страховими полісами 3 метою перетину державного кордону. Інші види страхування не набули широкого попиту у зв'язку з недовірою потенційних клієнтів через наявність на ринку шахрайських компаній.

Чинники розвитку інфраструктури ринку цінних паперів. Інфраструктура цінних паперів (фондового ринку) характеризується головним чином розміщенням у містах обласного та регіонального значення. Одним із учасників фондового ринку є інвестиційний фонд, вклади в який характеризуються популярністю через збереження та примноження заощаджень приватних осіб. У Західному регіоні України не представлена жодна 3 фондових бірж, яка зареєстрована в Україні Національною комісією 3 цінних паперів та фондового ринку. Проте, ще у XIX - на початку XX ст. у Львові була одна 3 перших бірж у межах сучасної України. На ринку, поряд iз перевіреними фондами, існують шахрайські утворення, які чинять негативний вплив на увесь сектор. Більшість операцій 3 купівлі-продажу цінних паперів (більше 90\%) відбуваються поза біржами, що відображає непрозорість ситуації. Власне, серед чинників, що гальмують розвиток інститутів спільного інвестування виділяємо їхнє локальне концентрування. На розміщення об'єктів інститутів спільного інвестування впливають показники рівня доходів населення, валовий регіональний продукт у розрахунку на одну особу, середньомісячна заробітна плата та демографічне навантаження населення, які дають змогу визначити інтенсивність та рівень розвитку інвестиційних фондів та його компонентів. Також простежується монопольність у Західному регіоні України, де найбільші потоки зосереджені на обласних центрах Львівської та Івано-Франківської областей (Kachmaryk, 2020).

Чинники розвитку інфраструктури ринку кредитних та фінансових послуг. Оскільки одним з особливих чинників Західного регіону України $\epsilon$ характерне переважання розвитку малого і середнього бізнесу над великим, то для західноукраїнського ринку важливим $\epsilon$ кредитування приватних осіб та малого бізнесу, натомість для великих бізнесових груп у цій сфері виникають ризики. Через це на ринку представлена незначна кількість банківських установ, які надають відповідні послуги для великого кредитування, через що спостерігається монополізація у цьому секторі. Розвитку малого кредитування сприяють програми, затверджені Кабміном. У поєднанні з особливими регіональними чинниками спостерігається здорова конкуренція між надавачами послуг, що сприяе стрімкому зростанню цього сектора фінансової інфраструктури.

Чинники розвитку

інфраструктури ринку послуг з фінансового лізингу. Цей ринок характеризується більшою стабільністю через те, що попит і пропозиція на ньому є менш рухливі, проте й найбільший рівень фінансового ризику і високий рівень дохідності також спостерігається у цій сфері. Цей ринок послуг характеризується слабо розвинутою інфраструктурою. Ця тенденція притаманна не лише для Західного регіону, а й для України загалом. В останні роки спостерігається розвиток, хоч його темпи залишаються повільними. Серед яскравих прикладів впровадження варто відзначити закупівлю великогабаритних автобусів Львівським комунальним автотранспортним підприємством № 1 (Lviv City Council, 2018). Тенденція із оновленням міського транспорту присутня в Ужгороді, Хмельницькому та Тернополі. 
Протягом 2020-2023 років у Львові у лізинг буде закуплено 250 електробусів, у Рівному планують закупити у лізинг сміттєвози, у Франківську автобуси, а у Чернівцях - тролейбуси.

Серед чинників розвитку інфраструктури недержавних пенсійних фондів варто відзначити їхню незахищеність від інфляції, а також наявність на ринку великої кількості шахрайських угрупувань. Оскільки недержавні пенсійні фонди запрацювали лише 32004 р., то станом на сьогодні ці установи фактично лише накопичують гроші вкладників.

Чинники розвитку інфраструктури банківських послуг. Для цієї інфраструктури характерні структурні зміни Національного банку України та банківської системи загалом. У зв'язку із впровадженням реформи децентралізації відбувається значне скорочення банківських відділень, що відображається у геопросторовому вимірі: у порівнянні з 2016 роком, у Західному регіоні у липні 2018 було закрито близько 380 відділень. А також вплив на скорочення територіальної мережі впливає тенденція діджиталізації банківських послуг. Важливим чинником є досвід кризи 2008 року, яку пережили не усі банки, а порятунком стало скорочення витрат через згортання територіальної мережі, що було впроваджено великими банками 3 іноземним капіталом. Відзначаємо, що скорочення відбулося також за рахунок закриття неплатоспроможних банків.

Чинники розвитку інфраструктури ринку 3 надання та реалізації конщесій. Інфраструктура цього ринку не функціонує належним чином ні у розрізі Західного регіону, ні в Україні загалом. Поперше, для цього сектору характерним $є$ довгий період окупності, а по-друге, у більшості випадків це спричинено тіньовою приватизацією.Існує велика кількість негативних прикладів, серед яких найчастіше суб'єктами підприємницької діяльності порушуються зобов'язання щодо реставрації/ побудови об'єктів комунальної власності на користь комерційних забудов.

Висновки. Перспективи фінансової інфраструктури Західного регіону України пов'язані як 3 загальносвітовими, загальнодержавними, так i регіональними та локальними тенденціями.

На наявний рівень розвитку фінансової інфраструктури Західного регіону України значний вплив мають такі суспільно-географічні чинники: географічне положення, історико-географічні особливості, соціально-географічні, економікогеографічні. Окрім перелічених вище чинників, які є традиційними, існують також інноваційні, до яких належать регіональне співробітництво, а також інвестиційні потоки (як внутрішньодержавні, так і зовнішні).
Загалом чинник географічного положення для розвитку фінансової інфраструктури Західного регіону України має стимулюючий характер, оскільки район дослідження виступає «воротами» до країн-членів Європейського Союзу.

Історико-географічний чинник також позитивно вплинув на формування фінансової інфраструктури: це знайшло своє відображення в утворенні особливої бізнес-мережі, яка активно розвивається у регіоні дослідження і нині. Крім цього, це виявилося у великій кількості місцевих банків та їх установ. Також це стосується кредитних установ.

Геопросторові особливості соціальногеографічних чинників характеризуються лімітуючими показниками для розвитку фінансової інфраструктури. Чисельність населення у регіоні скорочується, що призводить до зростання демографічного навантаження на населення. В цей же час варто наголосити, що серед інших вагомих чинників, демографічне навантаження на працездатне населення у Західному регіоні $\epsilon$ нижчим, ніж загальноукраїнське. Економікогеографічні чинники мають як стимулюючий, так і обмежуючий вплив: незважаючи на те, що окремі показники в районі мають рівень вище середньоукраїнського, але покази ВРП відображають загалом нижчий рівень економічного розвитку, ніж у решті регіонів, переважанням малого та середнього бізнесу над великими економікотворчими підприємствами; інвестиційна привабливість регіону спонукає до надходження коштів 3-за кордону, особливо країн-сусідів з ЄС. Не зважаючи на нижчий, ніж загальноукраїнський, рівень заробітної плати у регіоні дослідження, розвиток інфраструктури банківсько-кредитних установ має стрімкі темпи розвитку, що забезпечується шляхом укладання договорів 3 цими установами для посередництва у системі роботодавець-працівник. Обмежуючим чинником розвитку фінансової інфраструктури у Західному регіоні $є$ геопросторові особливості показників ВРП, що призвело до утворення значних диспропорцій у розвитку та функціонуванні фінансової інфраструктури регіону. Інноваційні чинники, такі як міжнародне співробітництво та інвестиційні потоки, особливо зовнішні, сприяють розвитку фінансової інфраструктури.

Території, віддалені від районних та обласних центрів, міст обласного значення, характеризуються нижчим рівнем соціальноекономічного розвитку. Загалом, для західних областей України характерним $є$ дисбаланс у розвитку фінансового ринку: метрополійно виділяється Львівська область, на яку припадає найбільша частка інвестицій у розвиток банківської інфраструктури.

\section{References:}

European Commision. (2020). Pan-European Corridors. Mobility and Transport. Access mode: https:/ec.europa.eu/transport/themes/infrastructure/studies/ten_t_en.

Fedosov, V. (2017). Theory of Finance. CUL. [In Ukrainian]. [Федосов В. М. Теорія фінансів. Підручник. ЦУЛ, 2017. 572 с.] 
Government Portal of Ukraine. (2020). The Infrastructure Reform in Ukraine. Access mode: https://www. kmu.gov.ua/diyalnist/reformi/ekonomichne-zrostannya/reforma-infrastrukturi. [In Ukrainian]. [Peфopмa інфраструктури в Україні / Урядовий портал [Електронний ресурс]. Режим доступу: https://www.kmu.gov. ua/diyalnist/reformi/ekonomichne-zrostannya/reforma-infrastrukturi.

International Bank for Reconstruction and Development. (2020). Financial Infrastructure. Building Access Through Transparent and Stable Financial Systems. Access mode: http://www.worldbank.org/nancialinfrastructure.

Ivanytska, O. (2005). State Regulation of Financial Infrastructure Development. Kyiv: NAPA Publishing House. [In Ukrainian]. [Іваницька О. М. Державне регулювання розвитку фінансової інфраструктури: Монографія. К.: Вид-во НАДУ, 2005. 276 с.]

Ivanytska, O. (2006). Conceptual approach to the regulation of financial infrastructure development in Ukraine. Public Administration: Theory and Practice, 1. [In Ukrainian]. [Іваницька О. М. Концептуальний підхід щодо регулювання розвитку фінансової інфраструктури в Україні // Державне управління: теорія та практика. 2006. № 1.]

Kachaev, Yu. (2000). Features of territorial development of the investment market of Ukraine. Ukrainian Geographical Journal, 3, 31-40.) [In Ukrainian]. [Качаєв Ю. Д. Особливості територіального розвитку інвестиційного ринку України // Український географічний журнал. 2000. № 3. С. 31-40.]

Kachmaryk, Z. (2018). Human-geographical aspects of the formation of the financial services market infrastructure of the Western region of Ukraine. In Shevchenkivska Vesna - 2018. Geography: Collection of Scientific Works of the XVI International Scientific Interdisciplinary Conference of Students, Postgraduates and Young Scientists (pp. 69-72). Kyiv: Print Service. [In Ukrainian]. [Качмарик 3. Р. Суспільно-географічні аспекти формування інфраструктури ринку фінансових послуг Західного регіону України / Шевченківська весна - 2018. Географія: Збірник наукових праць XVI міжнародної наукової міждисциплінарної конференції студентів, аспірантів та молодих вчених. Київ : ПрінтСервіс, 2018. С. 69-72.]

Kachmaryk, Z. (2020). Historical and geographical factors of formation of financial infrastructure in the Western region of Ukraine. In Region 2020: Strategy of Optimal Development (pp. 59-61). Kharkiv: V. N. Karazin Kharkiv National University. [In Ukrainian]. [Качмарик 3. Р. Історико-географічні чинники формування фінансової інфраструктури у Західному регіоні України / Регіон-2020: Суспільно-географічні аспекти: матеріали міжнародної науково-практичної конференції студентів, аспірантів та молодих науковців. Харків: ХНУ імені В.Н. Каразіна, 2020. С. 59-61]

Kachmaryk, Z. (2020). Human-geographical factors of formation of joint investment institutions in the Western region of Ukraine. In Region - 2020: Socio-Geographical Aspects: Materials of the International Scientific-Practical Conference of Students, Graduate Students and Young Scientists (pp. 59-61). Kharkiv: V. N. Karazin Kharkiv National University. [In Ukrainian]. [Качмарик 3. Р. Суспільно-географічні фактори формування інститутів спільного інвестування у Західному регіоні України / Регіон - 2020: Стратегія оптимального розвитку. Харків: ХНУ імені В.Н. Каразіна, 2020. С. 59-61.]

Kravtsiv, V. (2018). Territorial Development and Regional Policy in Ukraine: Challenges and Priorities of Ukraine. Lviv: Dolishny Institute of Regional Studies of the National Academy of Sciences of Ukraine [In Ukrainian]. [Кравців В. С. Територіальний розвиток і регіональна політика в Україні: Виклики та пріоритети України. Львів: ДУ «Інститут регіональних досліджень імені М. І. Долішнього НАН України», 2018. 157 с.]

Krykhovetska,Z. (2020). Directions of Development of Banking Services in Ukraine. [In Ukrainian]. [Криховецька 3. М. Напрями розвитку банківських послуг в Україні. Міжнародний центр науки і досліджень, 2020.]

Kuzhelev, M., Zhytar, M. (2015). Conceptual Bases of Efficiency of Financial Maintenance of Innovative Development of Ukraine. [In Ukrainian]. [Кужелєв М. О., Житарь М. О. Концептуальні засади ефективності фінансового забезпечення інноваційного розвитку України. Переяслав-Хмельницький: ДВНЗ “ПереяславХмельницький державний педагогічний університет імені Григорія Сковороди”, 2015. С. 14-18.]

Lviv City Council. (2018). Resolution of the Lviv City Council "On granting a permit to LC ATP № 1 for the purchase of rolling stock on the terms of financial leasing”. Access mode: https://www8.city-adm.lviv.ua/inteam/ uhvaly.nsf/(SearchForWeb)/FED958FB1292702ЕС22582650043A223?OpenDocument. [In Ukrainian]. [Ухвала ЛМР «Про надання ЛК АТП № 1 дозволу на закупівлю рухомого складу на умовах фінансового лізингу» [Електронний ресурс]. Режим доступу: https://www8.city-adm.lviv.ua/inteam/uhvaly.nsf/(SearchForWeb)/FED958 FB1292702EC22582650043A223?OpenDocument]

Mamchur, O., Kachmaryk, R. (2018). Financial infrastructure of the Western region of Ukraine: factors and socio-geographical aspects. In Geographical Science and Education: From the Statement to Constructivism (pp. 151-153). Kyiv, 2018. [In Ukrainian]. [Мамчур O. I., Качмарик О. I. Фінансова інфраструктура Західного регіону України: чинники та суспільно-географічні аспекти [Електронний ресурс] / Географічна наука та освіта: від констатації до конструктивізму: Зб. наук. праць. Київ, 2018. С. 151-153.]

Meglaperidze, A. (Ed.). (2013). Finances. Kyiv: Center for Educational Literature. [In Ukrainian]. [Меглаперідзе А.С. Фінанси. Навчальний посібник. / За заг. ред. Меглаперідзе А.С. Київ: «Центр учбової літератури», 2013. 420 c.]

Moshenskyi, S. (2014). Financial Centers of Ukraine and the Securities Market of the Industrial Era. London: Xlibris. [In Ukrainian]. [Мошенський С. 3. Фінансові центри України та ринок цінних паперів індустріальної епохи. London: Xlibris, 2014. 453 c.] 
National Bank of Ukraine. (2020). Currency market. Access mode: https://bank.gov.ua/ua/markets/currencymarket [In Ukrainian]. [Валютний ринок. Національний банк України [Електронний ресурс]. Режим доступу: https://bank.gov.ua/ua/markets/currency-market.]

National Commission for State Regulation of Financial Services Markets. (2020). Access mode: https://www.nfp. gov.ua. [In Ukrainian]. [Національна комісія, що здійснює державне регулювання у сфері ринків фінансових послуг [Електронний ресурc]. Режим доступу: https://www.nfp.gov.ua.]

National Institute for Strategic Studies. (2013a). Directions for Stimulating the Development of Small Business in the Peripheral Territories of the Western Regions of Ukraine. Analytical note. Access mode: http://old2.niss.gov. ua/articles/1290. [In Ukrainian]. [Напрями стимулювання розвитку малого підприємництва на периферійних територіях західних регіонів України. Аналітична записка // Національний інститут стратегічних досліджень. Режим доступу: http://old2.niss.gov.ua/articles/1290/]

National Institute for Strategic Studies. (2013b). Tools for Expanding the Market of Municipal Securities as a Factor of Resource Provision of Regional Development. Analytical note. Access mode: http://www.niss.gov.ua/ articles/1131. [In Ukrainian]. [Інструменти розширення ринку муніципальних цінних паперів як чинника ресурсного забезпечення регіонального розвитку. Аналітична записка / Національний інститут стратегічних досліджень [Електронний ресурс]. Режим доступу: http://www.niss.gov.ua/articles/1131.]

Peters, Edgar E. (1996). Chaos and Order in the Capital Markets: A New View of Cycles, Prices, and Market Volatility (2nd ed.). New York, USA: John Wiley \& Sons, Inc.

PJSC "KREDOBANK". (2020). Access mode: www.kredobank.com.ua/. [In Ukrainian]. [ПАТ "КРЕДОБАНК”. Офіційне інтернет-представництво [Електронний ресурс]. Режим доступу : www.kredobank.com.ua.]

Shabliy, O. (2012). Fundamentals of Human Geography. Lviv: Ivan Franko Lviv National University [In Ukrainian]. [Шаблій О. І. Основи суспільної географії: підруч. для студентів вищих навчальних закладів. - 2-ге видання. Львів: ЛНУ імені Івана Франка, 2012. 296 с.]

State Statistics Service of Ukraine. (2020). Access mode: http://www.ukrstat.gov.ua/. [In Ukrainian]. [Офіційний сайт Державної служби статистики України. Режим доступу: http://www.ukrstat.gov.ua/]

Zapotockiy, S. (2013). Regional Competitiveness as a Strategic Goal of Modern Regional Policy. Ekonomichna ta Sotsialna Geografiya, 1, 79-86. [In Ukrainian]. [Запотоцький С. П. Регіональна конкурентоспроможність як стратегічний напрям сучасної регіональної політики // Економічна та соціальна географія. 2013. № 1. С. 79-86] 